\title{
Scanning Electron Micrographic Investigation of Explanted (Used) Metallic Biomedical Implants for Corrosion and Other Mechanical Damage Responsible for Failure
}

\author{
Vaibhav Trivedi', Vishal Saxena1, Anupam Srivastav ${ }^{2 *}$ \\ ${ }^{1}$ Department of Mechanical Engineering, IFTM University, Moradabad, India \\ ${ }^{2}$ Middle East College, Knowledge Oasis Muscat, Muscat, Sultanate of Oman \\ Email: sri anupam2003@yahoo.co.in
}

Received 28 July 2015; accepted 17 October 2015; published 20 October 2015

Copyright (C) 2015 by authors and Scientific Research Publishing Inc.

This work is licensed under the Creative Commons Attribution International License (CC BY). http://creativecommons.org/licenses/by/4.0/

\section{(c) (i) Open Access}

\begin{abstract}
This paper deals with detailed corrosion analysis of explanted devices. The study of total 6 different types of orthopedic metallic implant was carried out after collecting the clinical report from the doctors, who performed these implantations. The clinical report covered the purpose of implantation, body part where implantation was done, and physiological reasons of removal of implant. The metallurgical investigation to study corrosion and any other mechanical damage to the implant surface during their service period was done using the Scanning Electron Micrography. SEM presented in this paper reveals the presence of in-vitro corrosion and mechanical damage as well, which are corroborating well with clinical reports.
\end{abstract}

Keywords

Implants, Corrosion, Fracture Surface, Scanning Electron Micrographs

\section{Introduction}

A material to be used as implant material for the human body should be biocompatible, that means, it should not cause any adverse reaction in the body. Such material must perform satisfactorily in the body environment

*Corresponding author.

How to cite this paper: Trivedi, V., Saxena, V. and Srivastav, A. (2015) Scanning Electron Micrographic Investigation of Explanted (Used) Metallic Biomedical Implants for Corrosion and Other Mechanical Damage Responsible for Failure. Materials Sciences and Applications, 6, 869-878. http://dx.doi.org/10.4236/msa.2015.610089 
without degrading till its intended use is over [1]. Corrosion of metal implants, which is one such degradation process, is critical because it can adversely affect the biocompatibility and mechanical properties. The materials used should not cause any adverse biological reaction in the body and, simultaneously, they must be stable retaining their functional properties. With the change in life style, implantation of biomedical (orthopedic) implants is being done in more young and active patients, than before. This necessitates the revision surgeries due to causes such as instability or dislocation of devices (41\%) [2], corrosion and galling damage, abrasion and wear, etc.

Corrosion is the first and most important consideration for any material to be selected as implant material because metal ion release takes place mainly due to corrosion of surgical implants [3]. Therefore, various in vitro and in vivo tests have to be carried out in order to identify appropriate materials for use as surgical implants. 316 $\mathrm{L}$ stainless steel is used in the medical field as an implant material due to its unique property of good corrosion resistance and biocompatibility. AISI $316 \mathrm{~L}$ stainless steel has very high corrosion resistance; it however degrades due to pitting in vivo [4] [5]. Type $316 \mathrm{~L}$ stainless steel and cast vitallium alloy are also known to undergo fretting corrosion. However, cast vitallium alloy has higher resistance to fretting corrosion than compared to 316 L SS [6].

Studies have shown that corrosion products and metal ions which are released in the body due to metal dissolution from the implant surface lead to adverse tissue reactions. Moreover, loss of surface passivation may result in stopping osseointegration [7]. Adverse tissue reaction and other biological risks involved with metal ions release are formation of wear debris, formation of colloidal organometallic complexes, release and accumulation of free metal ions, and inorganic metal salts or oxide formation [8]. Since corrosion of implant material results in loss of mechanical strength as well as toxic, allergic and idiosyncratic symptoms in patients, it needs special attention. It has been reported that in Co-Cr-Mo implants, the $\mathrm{Cr}$ is taken up by red blood cells, whereas Co is transported from tissues to the blood and is eliminated in the urine.

Although there are many studies reporting corrosion and mechanical damage of metallic implants in vivo, including detailed Scanning Electron Micrography [9]-[12], the authors do not find any work, particularly corresponding to patients in Indian subcontinent, where metallurgical investigations are corroborated with the clinical findings on the same implants.

\section{Materials \& Methods}

In this study, 6 different types of retrieved orthopedic implants have been collected, along with their other clinical details, such as name and sex of patient, name/type of implant, material specification and composition/ chemical constituents of the implant, purpose of implantation and reasons of removal. This information was collected from the patients' files with the permission of the Doctors. These implants were visually investigated for any signs of mechanical/corrosion degradation. The areas which had any signs of such damages were marked and were then subsequently investigated under higher magnification using SEM.

\section{Results \& Discussion}

\section{A. Clinical and Visual Investigation}

Clinical details of the retrieved implant, as mentioned above, are given in Table 1. The retrieved implants belong to five grades of $316 \mathrm{SS}$ and one grade of Titanium alloy. Types of implant are Inter locking femur nail, screw, plates and total hip implant.

As can be seen in Table 1, except for one 316 L SS implant at serial number 3 (95 DCS Plate) which was removed after successfully serving the intended period of use, and which was not reported to have manifested any adverse body response, all other implants were removed before completing their intended life in-vivo for reasons of adverse body/material responses such as pain and swelling in areas in body adjoining to the implant, mechanical instability inside body, pain while walking, or only pain with no swelling. Clinically it therefore proves that the adverse responses in patients requiring the implants to be removed before serving intended period of time was because of some types of deterioration in implant material. The chances of biomaterials centered infection (BCI) [13] has not been reported by the doctors as per Table 1. Similar such findings are reported in literature also [14]-[16].

Analysis of implant materials, type of implant as well as implantation purpose and location clearly indicates that both implant materials, the $316 \mathrm{~L}$ SS and Ti-6Al-4V alloy, show some adverse body reactions, during the 
Table 1. Clinical and material details of retrieved implants.

\begin{tabular}{|c|c|c|c|c|c|c|}
\hline S.N & Sex & Name of Implant & $\begin{array}{c}\text { Material } \\
\text { Specification }\end{array}$ & $\begin{array}{c}\text { Composition } \\
\text { of Material }\end{array}$ & $\begin{array}{c}\text { Reason of } \\
\text { Implantation }\end{array}$ & $\begin{array}{c}\text { Reason of Removal } \\
\text { of Implant }\end{array}$ \\
\hline 1 & Female & Interlocking femur & $\begin{array}{c}\text { SSEPL } \\
9 \mathrm{~mm} \times 360 \mathrm{~mm}\end{array}$ & $\begin{array}{ll}\text { - } & \text { Carbon } \\
\text { - } & \text { Chromium } \\
\text { - } & \text { Manganese } \\
\text { - } & \text { Molybdenum } \\
\text { - } & \text { Nickel } \\
\text { - } & \text { Silicon } \\
& \text { Sulphur }\end{array}$ & $\begin{array}{l}\text { Fracture } \\
\text { femur shaft }\end{array}$ & $\begin{array}{l}\text { Pain swelling } \\
\text { and mechanical } \\
\text { failure of implant }\end{array}$ \\
\hline 2 & Male & K. nail & $\begin{array}{c}\text { RNS } 316 \mathrm{~L} \\
10 \mathrm{~mm} \times 38 \mathrm{~cm}\end{array}$ & $\begin{array}{ll}\text { - } & \text { Carbon } \\
\text { - } & \text { Chromium } \\
\text { - } & \text { Manganese } \\
\text { - } & \text { Molybdenum } \\
\text { - } & \text { Nickel } \\
\text { - } & \text { Silicon } \\
\text { - } & \text { Sulphur }\end{array}$ & $\begin{array}{c}\text { Fracture femur } \\
\text { shaft } \\
\text { lower } 3 \mathrm{III}\end{array}$ & $\begin{array}{l}\text { Unstable, due to } \\
\text { wrong selection } \\
\text { of implant }\end{array}$ \\
\hline 3 & Male & 95 DCS plate & S $316 \mathrm{~L}$ & $\begin{array}{ll}\text { - } & \text { Carbon } \\
\text { - } & \text { Chromium } \\
\text { - } & \text { Manganese } \\
\text { - } & \text { Molybdenum } \\
\text { - } & \text { Nickel } \\
\text { - } & \text { Silicon } \\
\text { - } & \text { Sulphur }\end{array}$ & $\begin{array}{l}\text { Fracture } \\
\text { of femur }\end{array}$ & Completed service \\
\hline 4 & Female & $\begin{array}{l}\text { B. polar prosthesis } \\
\text { (total hip } \\
\text { replacement implant) }\end{array}$ & $\begin{array}{l}\text { INOR } \\
\text { SS } 316\end{array}$ & $\begin{array}{ll}\text { - } & \text { Carbon } \\
\text { - } & \text { Chromium } \\
\text { - } & \text { Manganese } \\
\text { - } & \text { Molybdenum } \\
\text { - } & \text { Nickel } \\
\text { - } & \text { Silicon } \\
\text { - } & \text { Sulphur }\end{array}$ & $\begin{array}{l}\text { Polyfracture } \\
\text { in hip }\end{array}$ & Pain in walking \\
\hline 5 & Male & Spinal screw & Ti 6AL4V & $\begin{array}{ll}\text { - } & \text { Titanium } \\
\text { - } & \text { Aluminum } \\
\text { - } & \text { Vanadium }\end{array}$ & Crack in spine & Pain \\
\hline 6 & Female & Cortical screw & S $316 \mathrm{~L}$ & $\begin{array}{ll}\text { - } & \text { Carbon } \\
\text { - } & \text { Chromium } \\
\text { - } & \text { Manganese } \\
\text { - } & \text { Molybdenum } \\
\text { - } & \text { Nickel } \\
\text { - } & \text { Silicon } \\
\text { - Sulphur }\end{array}$ & $\begin{array}{l}\text { Supporting } \\
\text { plate in leg }\end{array}$ & Swelling \& pain \\
\hline
\end{tabular}

implantation period. A close visual inspection with naked eye reveals signs of corrosion, mechanical damage, wear and fracture at the implant surface.

The retrieved implants are shown in Figure 1. The alpha-numeric numbers given to these figures correspond to the serial numbers of the implants listed in Table 1. The surfaces/areas of the implant having signs of corrosion, mechanical damage, wear and fractures during visual inspection are shown with arrows. These areas were then further investigated for detailed study using high magnification scanning electron micrography. For this purpose, the damaged/degraded part of the implants was carefully cut to obtain appropriate size samples for SEM.

\section{B. SEM Analysis}

SEM of retrieved implant (Figure 1(a) and Figure 1(b)) which had been reported (as per Table 1) to have caused swelling, pain and ultimately mechanical failure (fracture) of implant, was investigated further using SEM along the fractured surface marked in Figure 1(a) with vertical arrow and also near the screw hole, shown by horizontal arrow in Figure 2 and Figure 3. The figures show that the fractured surface has signs of crevice corrosion, which should be because of body fluids reaching the interior of the implant through the crevices and cracks/mechanical roughness present at the implant surface near the screw holes. Also, Figure 4 shows pitting corrosion near the screw holes. 


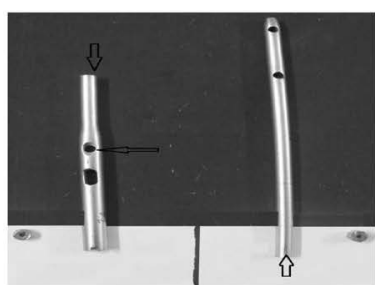

(a) (b)

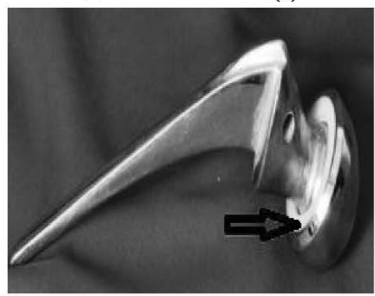

(f)

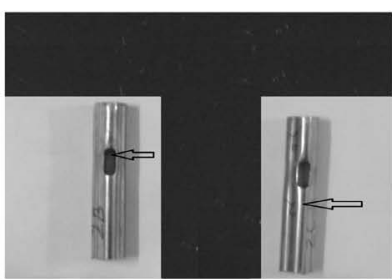

(c)

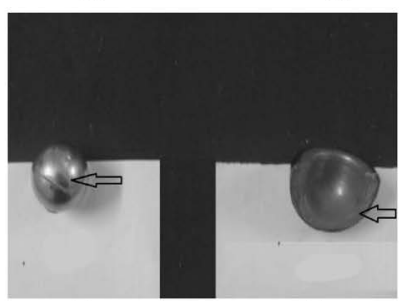

(g)

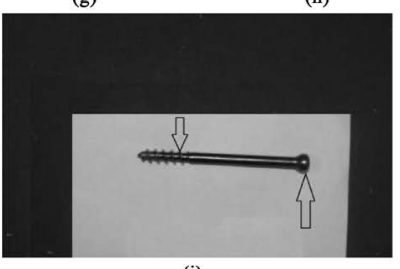

(j)

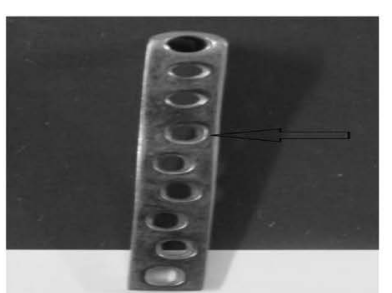

(e)

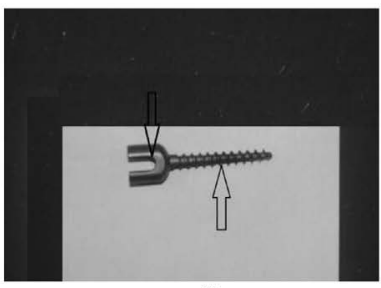

(i)

Figure 1. Surfaces/areas of the implant found during visual inspection to have signs of corrosion, mechanical damage, wear and fractures (shown with arrows) and used for SEM.

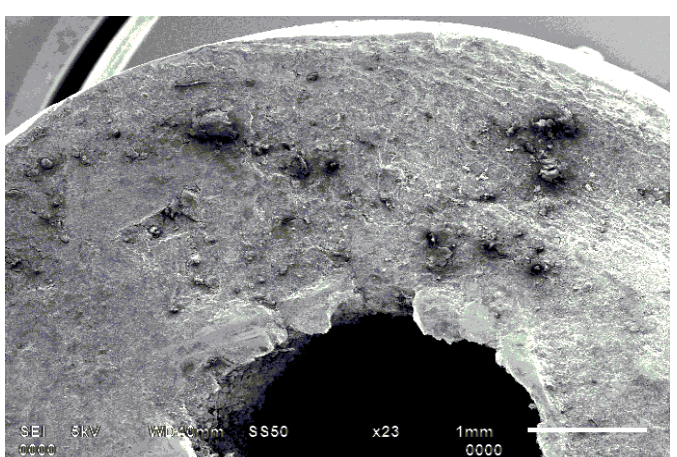

(a)

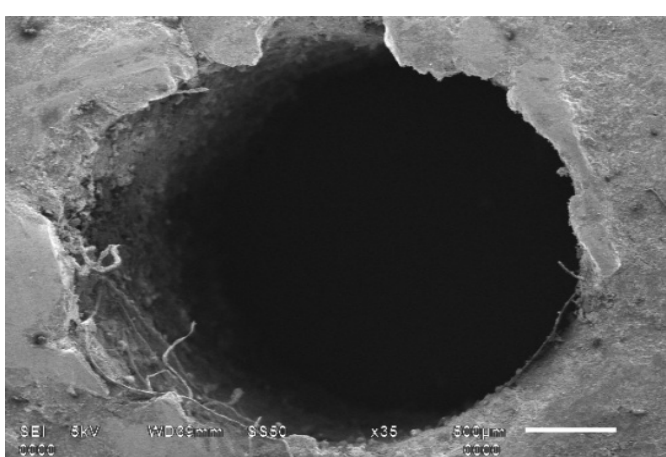

(b)

Figure 2. Low and high magnification SEM of fractured surface and internal hole of implant 1 revealing crevice corrosion and very rough internal surface which is the cause of seeping of body fluids through the crevices/cracks causing.

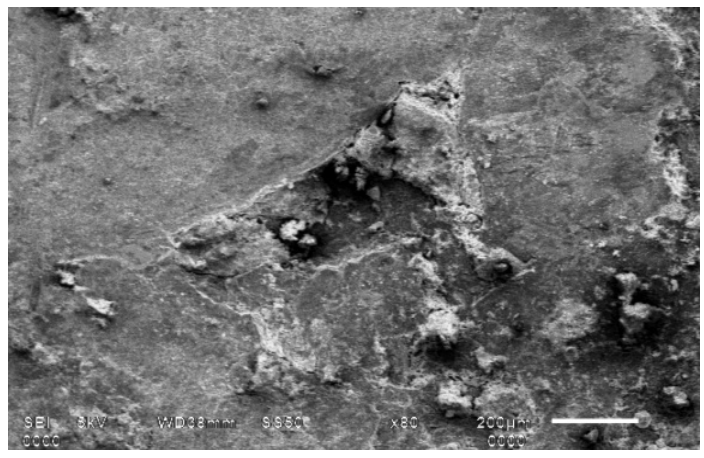

(a)

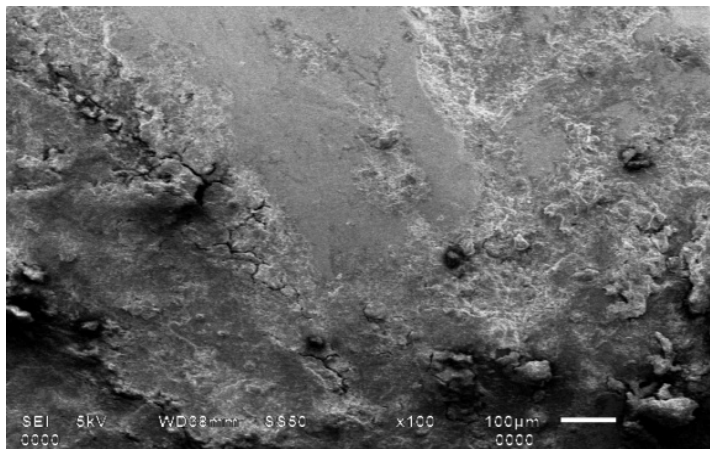

(b)

Figure 3. Higher magnification SEM of fractured surface showing large part of surface affected by crevice corrosion. 


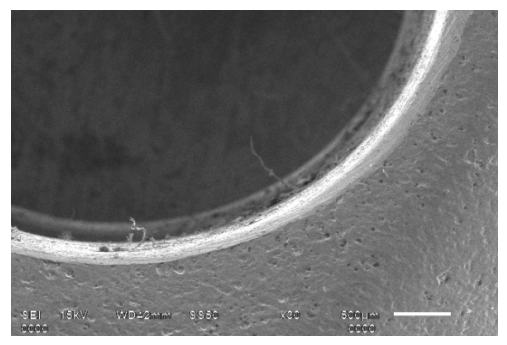

(a)

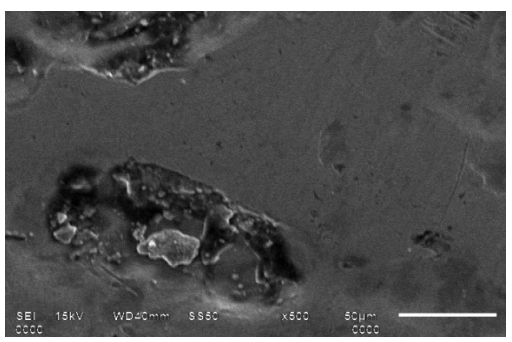

(b)

Figure 4. SEM of surface near the hole (Figure 1(a) horizontal arrow), showing pitting corrosion.

Material deterioration similar to that seen in Figure 3(a) and Figure 3(b), which also is crevice corrosion, can be seen in Figure 5(a) and Figure 5(b), which is SEM of other fractured part of the implant shown in Figure $1(b)$.

SEM of implant 2 at surfaces as marked by arrows in Figure 1(c) and Figure 1(d) are given in Figure 6(a), and Figure 6(b), as well as Figure 7(a) and Figure 7(b) and Figure 8(a) and Figure 8(b) respectively. It shows that areas close to the countersink hole have undergone substantial loss of material due to pitting corrosion.

Further, SEM of surface which was in direct contact with the tissues and body fluid, as represented by arrow in Figure 1(d), is shown in Figure 7(a) and Figure 7(b). This surface has some signs pitting and initial traces of corrosion at other places (dark patch in the figure).

Implant 3 had completed its intended life in-vivo. SEM for investigation of its surface at high magnification is given in Figure 8(a) and Figure 8(b). Figure 8(b) is the area shown by horizontal arrow in Figure 8(a), which corresponds to area shown by horizontal arrow in Figure 1(e). This investigation correlates well with clinical results (satisfactory performance of this implant), wherein because of very little corrosion, the implant seems to have performed well.

Implant 4 is total hip replacement (THR) implant which has a ball and socket joint of 316 L SS, with Ultra High Molecular Weight Polyethylene (UHMWPE) rubbing surface in the socket. The purpose of using UHMWPE is to reduce friction and wear between steel ball and socket. However, SEM, as shown in Figure 9(a) and Figure 9(b), shows that there was high contact pressure between UHMWPE surface and steel ball surface in the socket. This resulted in destruction of socket soft surface as a result of development of high temperature. This in turn resulted in melting and sticking of UHMWPE on to the steel ball surface. The black patches seen in Figure 9(a) are the transferred UHMWPE film on the steel ball surface. Furthermore, breakdown of UHMWPE surface seems to have resulted in steel to steel contact at some place where the UHMWPE layer has been destroyed. Because of steel to steel contact, the ball surface is subject to high friction and thus high contact temperature, which resulted in localized temporary welding and therefore lead to adhesive wear and fretting corrosion, as can be seen in Figure 9(b).

The damage to the UHMWPE socket surface due to extreme contact conditions is also confirmed by SEM shown in Figure 10(a) and Figure 10(b). These SEMs show typical worn and damaged surface of a plastic, thereby confirming the damage to the UHMWPE. Similar such deformations have been reported in literature as can be seen in Figure 11(a) and Figure 11(b) [17] but in simulated condition in vitro, wherein the light ploughs, similar to result found in this work as shown in Figure 10(a), indicate abrasion as the main wear mechanism and ripples due to plastic deformation. The pain in walking (reported in Table 1) by the patient can be attributed to reactions which the local tissue may have had with the wear debris generated by initial plaguing and plastic deformation and later fretting corrosion and adhesive wear of steel ball.

SEMs of implant 5, shown in Figure 12(a) and Figure 12(b), taken at surfaces near the spinal screw flutes clearly indicate evidence of fretting corrosion where there is some micro motion and Figure 13(a) and Figure 13(b) reveals crevice corrosion at the inner surface which has not experienced any micro motions. This is confirmed from literature also. The corrosion products from these two types of corrosion are responsible for pain (due to adverse tissue reaction) reported by the patient.

The SEM of implant 6 is shown in Figure 14(a) and Figure 14(b). This micrograph is taken at the surface near the screw head. These pictures reveal that the extent of deterioration due to corrosion, is very little, which is fretting, as reported earlier in this paper for other implants experiencing similar in-vivo conditions.

However, a look at the same screw near the screw flutes, given in Figure 15(a) and Figure 15(b), reveals more pronounced fretting corrosion. 


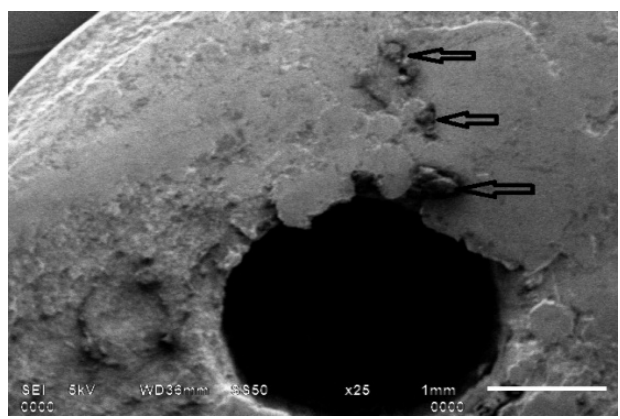

(a)

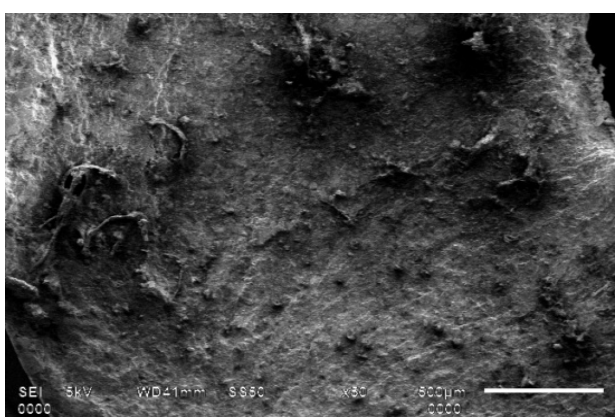

(b)

Figure 5. SEM of fracture surface other part of implant (figure 1B vertical arrow), showing crevice corrosion.

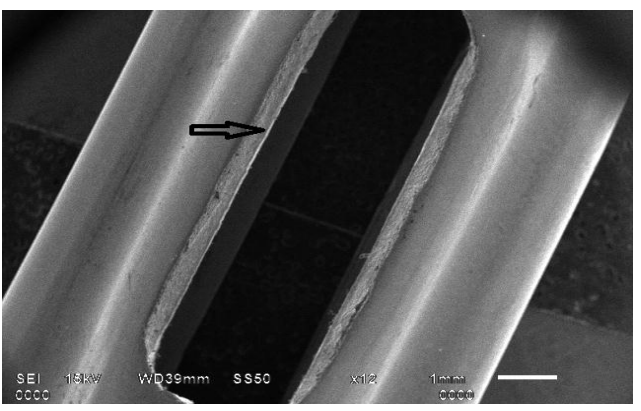

(a)

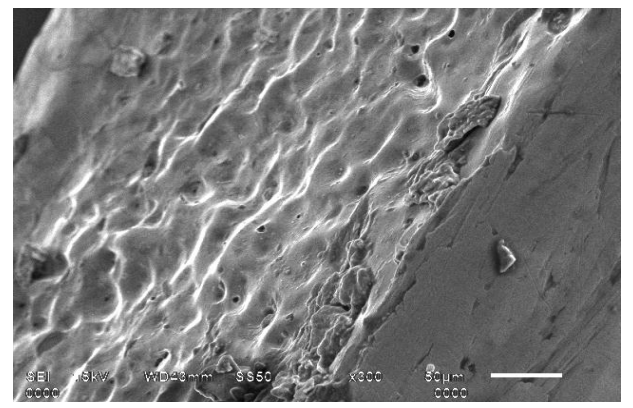

(b)

Figure 6. SEM of surface near the hole (Figure 1(c) area near arrow), showing serious pitting corrosion.

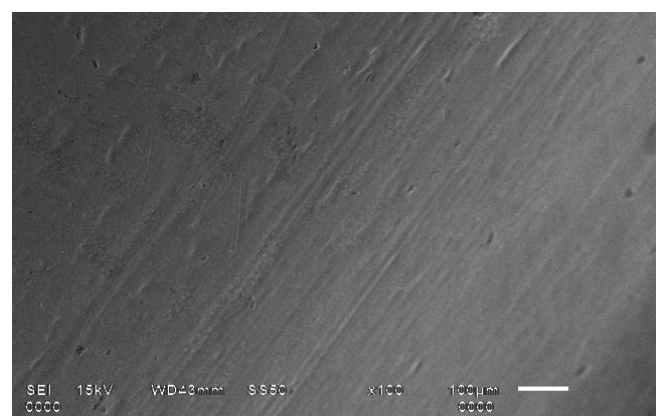

(a)

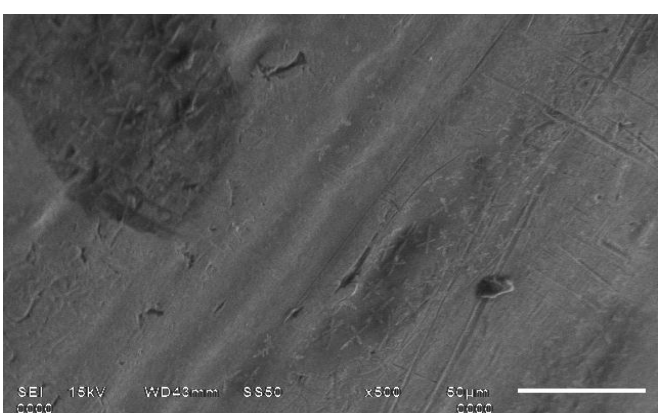

(b)

Figure 7. SEM of general surface of implant 2, small amount of pitting at few places and initial stages of corrosion at other places.

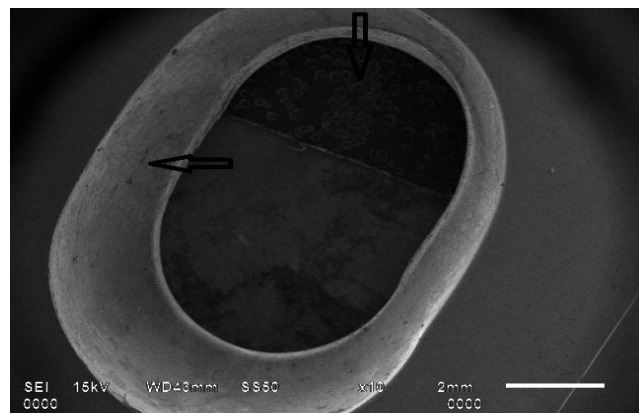

(a)

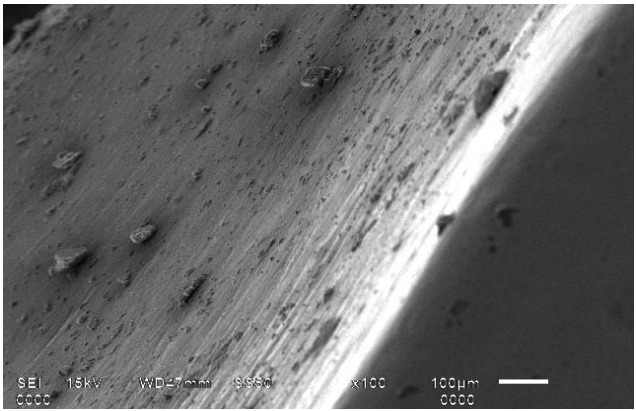

(b)

Figure 8. SEM of surface of implant 3 near the screw countersink hole with very insignificant and small amount of pitting corrosion. 


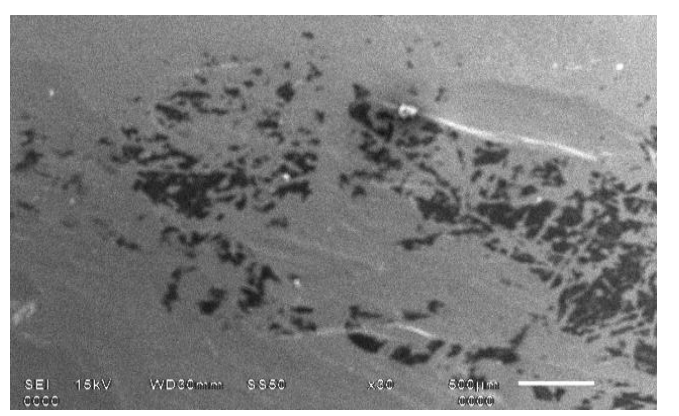

(a)

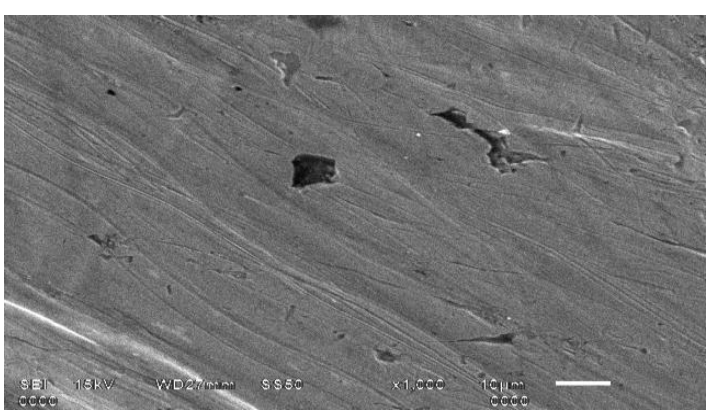

(b)

Figure 9. SEM of surface of implant 4 (steel ball) showing transferred UHMWPE on to the ball surface and adhesive as well as fretting corrosion on ball surface.

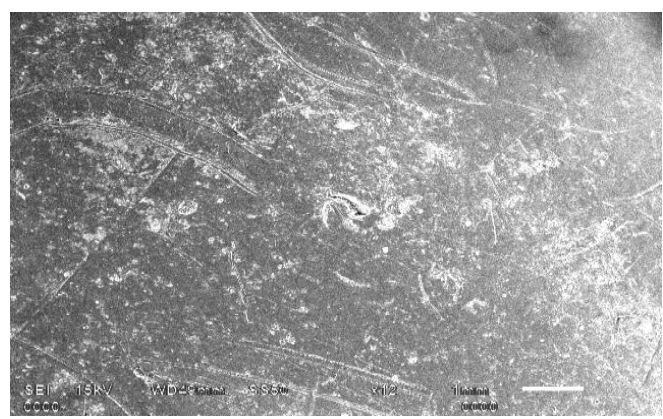

(a)

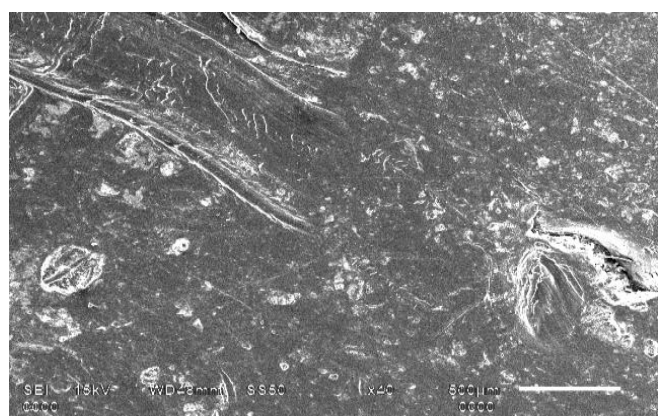

(b)

Figure 10. SEM of UHMWPE surface showing damage to the socket surface due to extreme contact conditions.

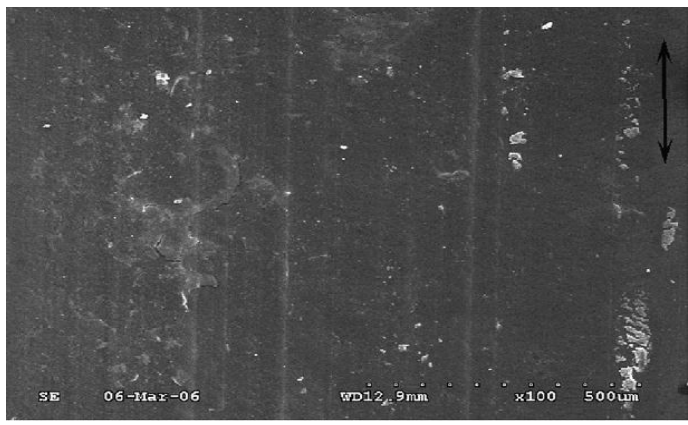

(a)

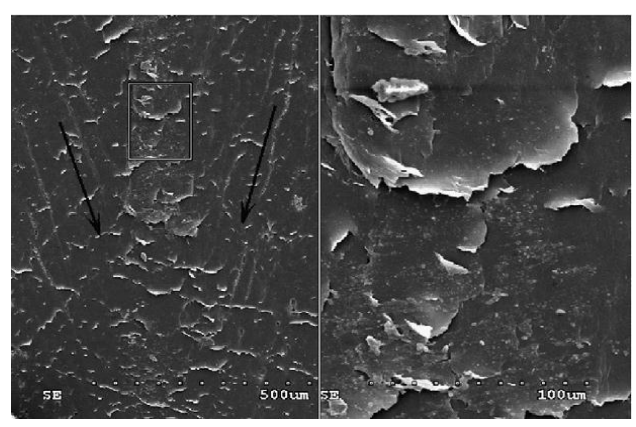

(b)

Figure 11. SEM observation of UHMWPE worn surface showing light ploughs (a) indicating abrasion as the main wear mechanism and ripples formed on the worn tracks (b) indicating plastic deformation in sliding contact area [17].

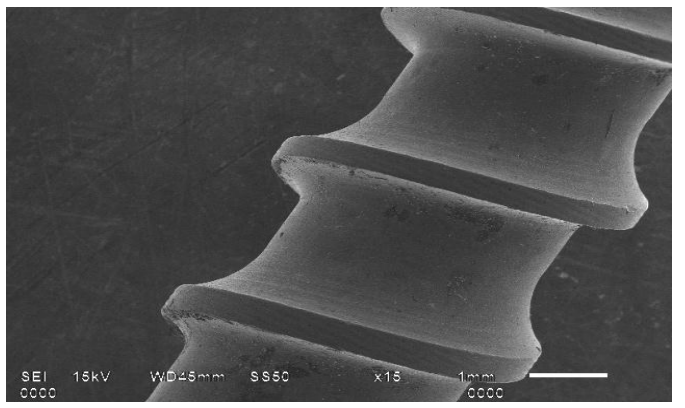

(a)

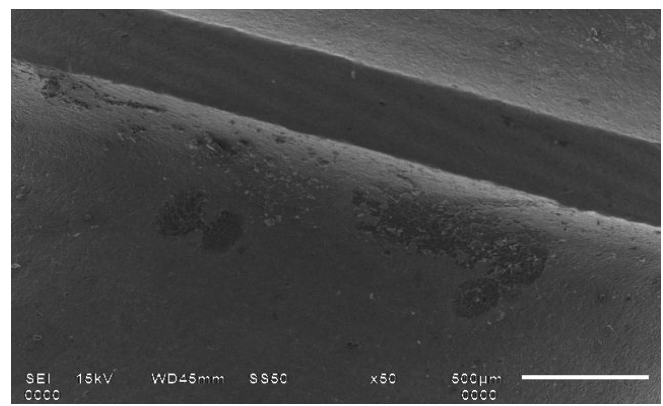

(b)

Figure 12. SEM of spinal screw surface showing fretting corrosion below the flute surface. 


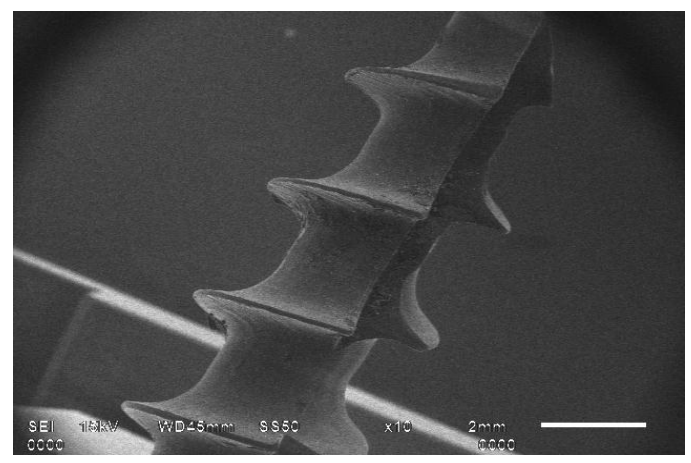

(a)

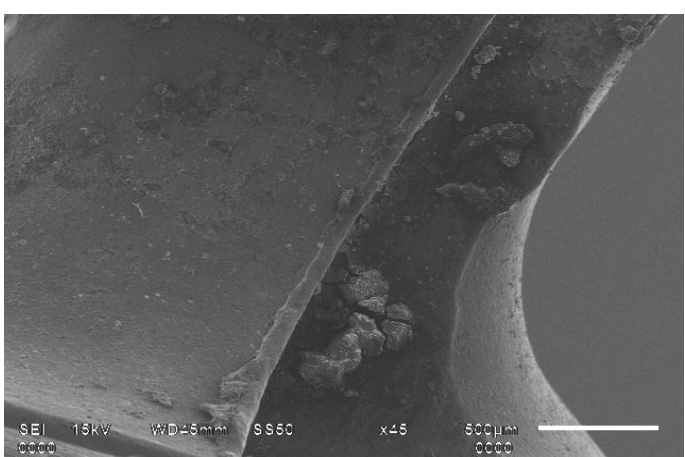

(b)

Figure 13. SEM of spinal screw surface showing crevice corrosion at the internal surface not in direct metal to metal contact.

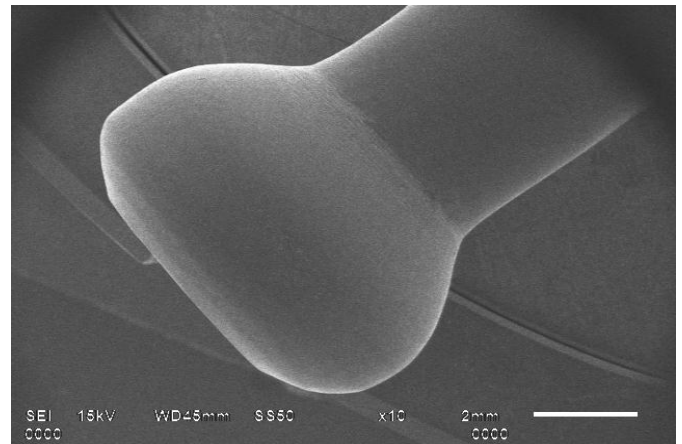

(a)

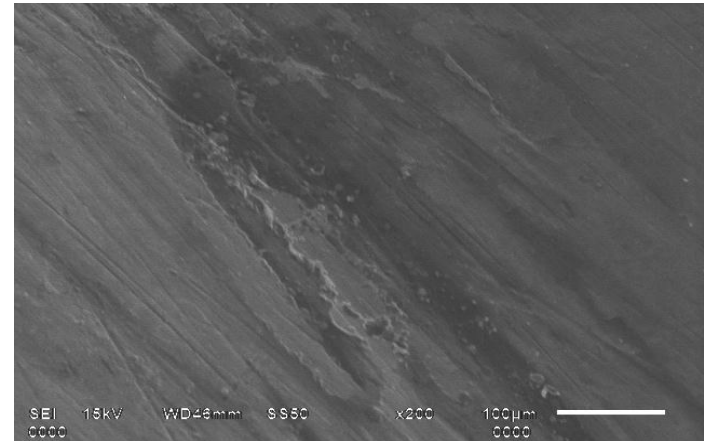

(b)

Figure 14. SEM of implant 6 (screw) taken at the screw head surface showing fretting.

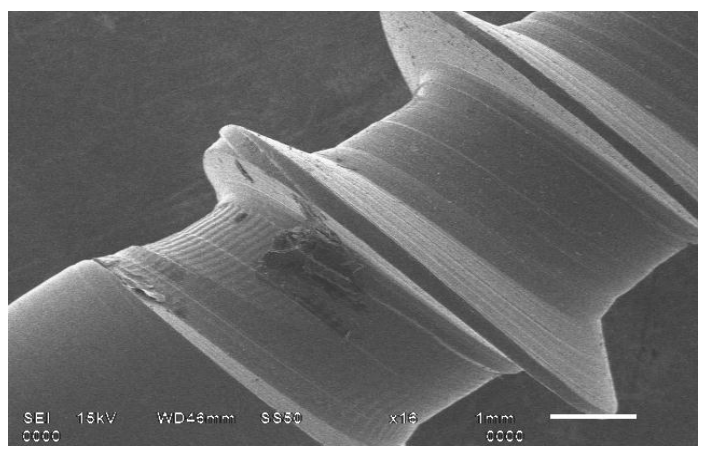

(a)

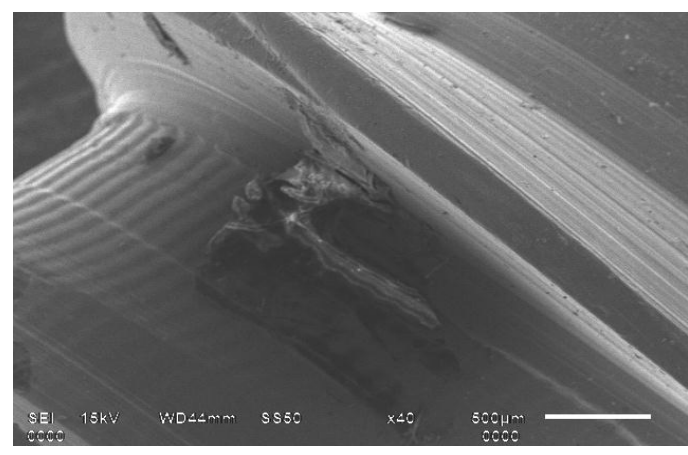

(b)

Figure 15. SEM of implant 6 (screw) taken at the screw flute surface showing severe fretting corrosion.

Analyzing these micrographs, it is found that pitting corrosion in these implants occurred at the exposed surface of the implant such as near the screw holes, which was in direct contact with the body fluids and tissues, thereby manifesting swelling and pain due to tissue reactions. Also, when the body fluids reach inside the material through the cracks and crevices, crevice corrosion is seen. Further, the implant areas which experience micro motion, apart from pitting and or crevice corrosion, fretting corrosion is also observed. Finally, in case of ball and socket joint implant of total hip replacement implant, damage to the UHMWPE acetabular cup surface happens due to plastic deformation and abrasion through steel ball surface, which later transfers to the steel ball surface also. Moreover, when UHMWPE surface is totally damaged, there is steel to steel contact leading to sever adhesive wear and pitting corrosion of steel ball surface. All these factors are responsible for manifestation of pain and swelling, due to wear debris and corrosion products reacting adversely with local tissues in the presence of body fluid. 


\section{Conclusions}

Based on the clinical report and metallurgical investigation using SEM carried out in this work on explanted orthopedic metallic implants, following conclusions are drawn:

1) Physiological symptoms such as pain and swelling adjoining the implanted region as well as mechanical failure of implant resulting in removal of implant before completion of intended service period are due to corrosion and wear rather than faulty selection of implant or biocompatibility mismatch between implant and patients' body.

2) Even in case where implant serves its short intended service period in vivo, it shows signs of corrosion and that it will have ultimately failed if used for longer duration.

3) Crevice and pitting corrosions are the mechanisms with which the implant deteriorates because of body fluids reaching the interior of the implant through the crevices and cracks/mechanical roughness present at the implant surface near the screw holes.

4) The areas which have higher mechanical stress levels, such as countersink hole, undergone substantial loss of material due to pitting corrosion.

5) In case of implants such as THR, where there is contact between two dissimilar materials, one soft (UHMWPE) and other hard (Steel), adhesive wear takes place on harder surface and abrasive wear on softer, in addition to fretting corrosion of metallic surface.

6) Any implant surface which experiences micro motion, such as screw, undergoes fretting corrosion in presence of body fluids.

7) To increase the life of implant and avoid adverse body reactions and pain, the issue of corrosion resistance is the most important challenge to be addressed while developing newer implant materials.

\section{Conflict of Interest}

The authors confirm that this article has no conflict of interest.

\section{Acknowledgements}

This paper is a part of the PhD work of first author, under supervision of other two authors, carried out at IFTM University, Moradabad, India. The authors thank the Management and Vice chancellor of IFTM University, for providing the necessary facilities and permission to carry out the work.

\section{References}

[1] Fraker, A.C. (1992) Corrosion, ASM Handbook. ASM International, 13, 1324-1335.

[2] Speirs, A.D., Nganbe, M., Louati, H, Khan, U. and Beaulé, P.E. (2010) In Vitro and Retrieval Analysis of Modular Necks in Total Hip Arthroplasty. Proceedings of 56th Annual Meeting of the Orthopaedic Research Society, McKay Orthopaedic Laboratory, University of Pennsylvania, Philadelphia, 6-9 March 2010, pp.

[3] Gonzalez, J.E.G. and Mirza-Rosca, J.C. (1999) Study of the Corrosion Behavior of Titanium and Some of Its Alloys for Biomedical and Dental Implant Applications. Journal of Electroanalytical Chemistry, 471, 109-115. http://dx.doi.org/10.1016/S0022-0728(99)00260-0

[4] Kannan, S., Balamurugan, A. and Rajeswari, S. (2005) Electrochemical Characterization of Hydroxyapatite Coatings on $\mathrm{HNO}_{3}$ Passivated 316L SS for Implant Applications. Electrochimicaacta, 50, 2065-2072. http://dx.doi.org/10.1016/j.electacta.2004.09.015

[5] Fossati, A., Borgioli, F., Galvanetto, E. and Bacci, T. (2006) Glow Discharge Nitriding of AISI 316L Austenitic Stainless Steel: Influence of Treatment Time. Surface \& Coatings Technology, 200, 3511-3517. http://dx.doi.org/10.1016/j.surfcoat.2004.10.122

[6] Syrett, B.C. and Wing, S.S. (1978) An Electrochemical Investigation of Fretting Corrosion of Surgical Implant Materials. Corrosion, 34, 378-386. http://dx.doi.org/10.5006/0010-9312-34.11.378

[7] Rodrigues, D.C., Valderrama, P., Wilson Jr., T.G., Palmer, K., Thomas, A., Sridhar, S., Adapalli, A., Burbano, M. and Wadhwani, C. (2013) Titanium Corrosion Mechanisms in the Oral Environment: A Retrieval Study. Materials, 6, 5258-5274. http://dx.doi.org/10.3390/ma6115258

[8] Sargeant, A. and Goswami, T. (2007) Hip Impants-Ion concentrations. Materials \& Design, 28, 155-171. http://dx.doi.org/10.1016/i.matdes.2005.05.018

[9] Cheng, Y., Hu, J., Zhang, C., Wang, Z., Hao, Y. and Gao, B. (2013) Corrosion Behavior of Novel Ti-24Nb-4Zr-7.9Sn 
Alloy for Dental Implant Applications in Vitro. Journal of Biomedical Materials Research Part B, 101, $287-294$. http://dx.doi.org/10.1002/jbm.b.32838

[10] Waddell, J.N., Payne, A.G.T. and Kieser, J.A. (2010) Scanning Electron Microscopy Observations of Failures of Implant Overdenture Bars: A Case Series Report. Clinical Implant Dentistry and Related Research, 12, 26-38. http://dx.doi.org/10.1111/j.1708-8208.2008.00127.x

[11] Rodrigues, D.C., Urban, R.M., Jacobs, J.J. and Gilbert, J.L. (2009) In Vivo Severe Corrosion and Hydrogen Embrittlement of Retrieved Modular Body Titanium Alloy Hip-Implants. Journal of Biomedical Materials Research Part B: Applied Biomaterials, 88, 206-219. http://dx.doi.org/10.1002/jbm.b.31171

[12] Suito, H., Iwawaki, Y., Goto, T., Tomotake, Y. and Ichikawa, T. (2013) Oral Factors Affecting Titanium Elution and Corrosion: An in Vitro Study Using Simulated Body Fluid. PLoS ONE, 8. http://dx.doi.org/10.1371/journal.pone.0066052

[13] Gristina, A.G. (1987) Biomaterial-Centered Infection: Microbial Adhesion versus Tissue Integration. Science, 237, 1588-1595. http://dx.doi.org/10.1126/science.3629258

[14] Uhthoff, H.K., Poitras, P. and Backman, D.S. (2006) Internal Plate Fixation of Fractures: Short History and Recent Developments. Journal of Orthopaedic Science, 11, 118-126. http://dx.doi.org/10.1007/s00776-005-0984-7

[15] Singh, R. and Dahotre, N.B. (2007) Corrosion Degradation and Prevention by Surface Modification of Biometallic Materials. Journal of Materials Science: Materials in Medicine, 18, 725-751. http://dx.doi.org/10.1007/s10856-006-0016-y

[16] Fontana, M.G. (1987) Corrosion Engineering. 3rd Edition, McGraw-Hill, Singapore.

[17] Gea, S., Wang, S., Gitis, N., Vinogradov, M. and Xiao, J. (2008) Wear Behavior and Wear Debris Distribution of UHMWPE against Si3N4 Ball in Bi-Directional Sliding. Wear, 264, 571-578.

http://dx.doi.org/10.1016/j.wear.2007.05.001 